\title{
AMENDMENTS
}

\section{Author Correction: Meta-DNA structures}

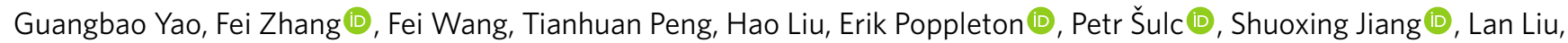
Chen Gong, Xinxin Jing, Xiaoguo Liu (1), Lihua Wang, Yan Liu (D), Chunhai Fan (1D and Hao Yan (D)

Correction to: Nature Chemistry https://doi.org/10.1038/s41557-020-0539-8, published online 7 September 2020.

The authors feel that some relevant references were missing from the version of this Article originally published; the newly added references 44-47 have been cited in a new paragraph, beginning 'Our approach can be contrasted to', which precedes the 'Results and discussion' section. These changes have now been made.

Published online: 24 November 2020

https://doi.org/10.1038/s41557-020-00611-z

() The Author(s), under exclusive licence to Springer Nature Limited 2020

\section{Publisher Correction: A platinum(II) metallonitrene with a triplet ground state}

Jian Sun (D), Josh Abbenseth, Hendrik Verplancke (D), Martin Diefenbach, Bas de Bruin (D), David Hunger, Christian Würtele, Joris van Slageren (D), Max C. Holthausen (D) and Sven Schneider (D)

Correction to: Nature Chemistry https://doi.org/10.1038/s41557-020-0522-4, published online 24 August 2020.

In the version of this Article originally published, in the Acknowledgements section, one of the grant numbers was given as 'SA1840/7'; it should have been 'SCHN950/6-1'. This has now been corrected.

Published online: 16 December 2020

https://doi.org/10.1038/s41557-020-00613-x

(C) The Author(s), under exclusive licence to Springer Nature Limited 2020

\section{Publisher Correction: Enantioselective $\mathrm{C}\left(s p^{3}\right)-\mathrm{C}\left(s p^{3}\right)$ cross-coupling of non-activated alkyl electrophiles via nickel hydride catalysis}

Srikrishna Bera (D), Runze Mao (D) and Xile Hu(D)

Correction to: Nature Chemistry https://doi.org/10.1038/s41557-020-00576-z, published online 30 December 2020.

In the version of this Article originally published, in Fig. $1 \mathrm{~d}$, ' $\left[\mathrm{H}_{3} \mathrm{Si}\right]-\mathrm{H}$ ' should have been '[Si]-H'. In Fig. 2b, 'Boc' should have been ' $\mathrm{Boc}_{2} \mathrm{O}$ '. In Fig. 3e, '(EtO $)_{2} \mathrm{MeSiH}_{2}-\mathrm{H}^{\prime}$ and '(EtO) ${ }_{2} \mathrm{MeSiH}_{2}-\mathrm{I}$ ' should have been '(EtO $)_{2} \mathrm{MeSi}-\mathrm{H}$ ' and '(EtO) ${ }_{2} \mathrm{MeSi}-\mathrm{I}$ ', respectively. In addition, the footnotes of Tables 2 and 3 should have read 'L6' instead of 'L12'. These corrections have now been made.

Published online: 8 February 2021

https://doi.org/10.1038/s41557-021-00649-7

(C) The Author(s), under exclusive licence to Springer Nature Limited 2021 